\title{
The Importance of the Business Plan TO THE SMALL BUSINESS
}

\author{
Cynthia C. Ryans \\ Department of Library Administration \\ Kent State University \\ Kent, Ohio \\ John K. Ryans, Jr. \\ Michael A. Pearson \\ College of Business Administration \\ Kent State University \\ Kent, Ohio
}

Some feel a good business plan can greatly increase any start-up or early-stage small business's chances for success. But good business plans are not always easy to develop. Often, the preparation of a business plan is one of the most difficult tasks to tackle and complete.

In a 1985 survey Ackelsberg and Arlow [1] reported that the majority of responding small-business firms do plan. The researchers demonstrated that organizations which engaged in planning had greater increases in sales and profits over a three-year period than non-planning organizations.

If a business plan is lacking, it is quite possible that the marketing, production, finance, and other functions of the business will each operate under individual guidelines that might be directed toward different and conflicting goals. A sound business plan can go a long way toward avoiding such a situation. In this article various aspects of the business planning process will be explored, and the importance of the business plan for small businesses will be discussed. The results of a study conducted among faculty teaching small-business courses provide particular insights on this topic.

\section{What Is a Business Plan?}

Two definitions of a business plan suggest its breadth and content. Bryan and Welton $([2]$, p. 44) define a business plan as "a detailed written description of a company's past, current, and projected operations." According to Welsh and White $([11]$, p. 300), " $(t)$ he plan for a new business is the description, in precise and concise language, of the activities that will take place and the net result of the exchanges of value in the transactions that will occur during the early months and years in the life of a new enterprise."

Journal of Business Strategies, Volume 5, Number 2 (Fall 1988) 
Many will argue that it is actually the ability (or lack of ability) to develop a business plan which establishes the likelihood of a small firm's ultimate success or failure. If, for example, the management of a new business merely has a single "good idea" relating to a potential new product and forges ahead without a clear understanding of how to implement that idea, then the business is probably destined for failure. King [4] states that according to the Small Business Administration, lack of planning is one of the two major causes of business failure (lack of capital is the other).

Businesses do fail, and by any measure, they fail all too often. In 1986, there were more than 80,000 small-business bankruptcies [10].

Despite such a large number of small-business failures, some owners and managers of small firms feel their businesses are not suited for anything as formal as a business plan. Their claim is that the operation of a business needs to be flexible and ready to change direction quickly; they see a business plan as inhibiting that flexibility. Larson [5] points out that even some well-known businesses do not employ a formal planning process. The managements of these firms believe business plans are simply "dreams of glory" and enjoy listing all the companies that have been successful without relying on a business plan.

Although some organizations have shown they can "make it" without formal planning, most small businesses would be wise not to take the chance. For many small firms there is no choice. To a start-up company seeking venture capital, a spot in a business incubator facility, or a small-business grant or bank loan, the preparation of a business plan is likely to be a necessity. If resources are being requested by an organization, management will undoubtedly be required to demonstrate how they are to be used.

Even for a fully-funded start-up or early-stage small business, going through the steps in the business planning process should help to improve its probability of success. Preparing a business plan forces the smaller firm to carefully identify its goals and outline what it views as a realistic course to achieve them.

In addition to goals and expected courses of action, the business plan typically should specify a company's short-and longer-term financial needs, personnel requirements, manufacturing requisites (if appropriate), and projections of both a financial and market nature. In effect, what the business plan should contain are all of the elements needed to ensure that the firm knows exactly what is required to survive the critical infancy stage and initial years and then move on to a prosperous future. A good business plan minimizes surprises and encourages systematic operations.

\section{Business Plan Coverage in Small-Business Courses}

To determine what topics are being included in basic Small Business Management courses at the college level today, an extensive survey was conducted among faculty members who are involved in teaching or administrating courses in small business. The survey was sent to 250 community/junior colleges and four-year colleges and universities in the United States and Canada, with 110 being returned and employed in this analysis (a 44 percent response rate). 
The survey results indicate "the business plan" is rated highest in importance among the various topics given course consideration. Table 1 presents the respondents' ratings of 20 topics sometimes covered in the basic Small Business Management course.

\section{Table 1}

\section{Ratings of Small Business Management Course Topics}

Question: How important do you feel each of the following topics is for coverage in a Small Business Management

\begin{tabular}{|c|c|c|c|c|}
\hline & \multicolumn{4}{|c|}{ course at a basic level? } \\
\hline & \multirow{2}{*}{$\begin{array}{c}\text { Not } \\
\text { Important }\end{array}$} & \multirow{2}{*}{\multicolumn{2}{|c|}{$\begin{array}{l}\text { Percent Responding } \\
\text { Somewhat }\end{array}$}} & \multirow{2}{*}{$\begin{array}{c}\text { Very } \\
\text { Important }\end{array}$} \\
\hline & & $\begin{array}{l}\text { Somewhat } \\
\text { Important }\end{array}$ & & \\
\hline Accounting & 1 & 23 & 45 & 28 \\
\hline Auditing & 62 & 28 & 6 & 1 \\
\hline Business Law & 6 & 37 & 40 & 14 \\
\hline Business Plan & 0 & 2 & 16 & 81 \\
\hline Entrepreneurship & 3 & 14 & 36 & 46 \\
\hline Finance & 0 & 17 & 50 & 29 \\
\hline \multicolumn{5}{|l|}{ Form of Business } \\
\hline Organization & 3 & 36 & 36 & 23 \\
\hline Government Relations & 10 & 53 & 26 & 9 \\
\hline Insurance & 9 & 37 & 41 & 10 \\
\hline Internal Control & 5 & 24 & 45 & 23 \\
\hline Management & 0 & 10 & 46 & 41 \\
\hline Marketing & 0 & 3 & 34 & 61 \\
\hline Office Management & 18 & 41 & 36 & 3 \\
\hline Organizational Behavior & 15 & 41 & 31 & 12 \\
\hline Personnel & 5 & 34 & 43 & 16 \\
\hline Real Estate & 41 & 43 & 13 & 1 \\
\hline Sales Management & 2 & 29 & 16 & 21 \\
\hline Taxes & 3 & 30 & 47 & 18 \\
\hline Venture Capital & 4 & 36 & 35 & 24 \\
\hline Women/Minorities in & & & & \\
\hline Small Business & 23 & 46 & 22 & 7 \\
\hline
\end{tabular}

Source: Authors' survey of faculty members who are teaching or administrating courses in small-business management. Results are based on replies from 110 respondents. Percentages are rounded and do not iotal 100 percent because not all respondents rated each topic.

Note that over 80 percent of the academics believe the business plan is a "Very Important" topic for inclusion in a basic course in Small Business Management, with 
none of respondents rating the business plan as an unimportant topic. Hence, it appears almost certain that small-businesspersons (or aspiring small-businesspersons) who enroll in a Small Business Management course can expect that business plans will be given extensive coverage.

Among the remaining topics listed on the survey, only marketing is felt to be "Very Important" by over half of the faculty participating in the study. Approximately 61 percent give marketing this rating. Other topics receiving relatively high ratings are entrepreneurship, general management, sales management, finance, accounting, taxes, and internal control.

Several of the syllabuses received as another part of the research project indicate that instructors sometimes include the writing of a business plan as one of the course requirements. For example, some teachers require students to prepare a business plan, focusing primarily on what work is to be done, how it is to be done, and who will be doing it. Students may also be expected to predict the time constraints under which their proposals will be operating, and then describe how to monitor the company's activities in order to meet the goals of the proposed business plan. Other instructors require students to develop a business plan specifically for the purpose of obtaining venture capital. Still others ask students to write a business plan that includes extensive details on strategy and tactics.

These syllabuses further indicate that the emphasis in many small-business courses is on becoming a successful entrepreneur. While there are numerous activities that must be mastered before an entrepreneur can successfully operate any type of small business, instructors realize that the development, execution, reevaluation, and updating of a business plan is one of the more important aspects of small-business management.

In summary, our survey results suggest that respondents believe the business plan plays a significant role in small-business operations. To betier prepare their students, many of the respondent college instructors have reinforced this notion by including the business plan as an integral part of their curriculums. It seems apparent that teachers of small business courses are of the opinion that the benefits of conducting business with a good business plan far outweigh the costs of preparing one.

\section{Responsibility for Developing the Business Plan}

It is important that those charged with writing the business plan have the necessary expertise to accomplish the task successfully. This includes knowing how to develop goals for an organization and recognizing whom to contact for information. Over 50 percent of the respondents to a recent Venture magazine survey [6] indicated that their planning input comes entirely from top management, while 24 percent work with department-head level personnel in developing business plans.

How does the small-businessperson obtain expertise in preparing a business plan? Unfortunately, many learn through trial-and-error. Some, on the ather hand, develop proficiency by working with paid consultants. Other small-businesspersons have taken it woon themselves to research extensively the plan-preparation process. 
Another way to hone business plan writing skills is to take advantage of educational programs offered by local institutions of higher education, including courses, workshops, and seminars. Off-site management retreats for key planners are still another possibility.

Finally, the many services offered by the Small Busitiess Administration (SBA) should not be overlooked [9]. For example, the SBA provides management assistance programs, help for minority businesses, and the volunteer support of the Service Corps of Retired Executives (SCORE). Additionally, many colleges and universities offer various consultation services through entrepreneurship centers and small business institutes, many of which have been formed in conjunction with the SBA's Small Business Institutes program. This particular program provides small firms with the free counsel of graduate business students.

\section{Preparing the Business Plan}

King ([4], p. 6) claims there are three basic questions that should be answered when writing a business plan: "What business is my company in; where do we want to go; how do we want to get there?" Hankin and Bagg $[3 \mid$ advise that business plans include the firm's objectives; the ongoing planning system; and the who, what, where, when, and how of the business's needs. The authors suggest that detailed descriptions of the kcy people in the organization are especially needed. Two other writers, Ormerod and Burns [7], offer seven tips for those preparing a business plan: market the managcment, establish a distinctive competence, address risks, set benchmarks, summarize the key points, keep the document short, and consider the reader. ${ }^{1}$

The content of the business plan is of the utmost importance, yet the packaging of the plan can also be a critical factor. At times, the packaging just might be the deciding factor on a funding decision. Potential investors could view a poorlypackaged business plan as evidence that a business will not be managed well. Rich and Gumpert [8] suggest that plan writers pay particular attention to the appearance (should be neat but not overdone); the length (should not exceed 40 pages in length); the title page (should contain the name, address, and phone number of the company, as well as the current date); the table of contents (should list each of the business plan's sections); and the executive summary (should explain in about two pages the present status of the company, its products and services, financial forecasts, venture's objectives, and amount of financing needed).

Business plans are not "all things to all people," and some of the advantages and disadvantages should be mentioned or reiterated. A good plan can help to pinpoint strengths and weaknesses in an organization and provide an outline that enables the owners and managers to see all sides of the business. A business plan can be used as a management tool and as a device for obtaining venture capital. It can provide a blueprint for defining potential risks, outlining the needs of the business, projecting product pricings, and planning the directions the business should take. Preparing a

\footnotetext{
${ }^{1}$ Although there are a number of ways to present a business plan, one typical approach appears in outline form in the Appendix.
} 
business plan offers one the opportunity to think through all facets of the business. The business plan can also be used as a tool to evaluate the operation of the business on a regular basis. It is critical to remember that a business plan is never finished; it should be evaluated and updated constantly.

Not everything about a business plan is necessarily viewed as positive. Some small-business owners and managers do not believe the plans are worthwhile. Some claim a business plan requires an excessive amount of time to complete. Some feel business plans, if prepared too comprehensively, cause owners and managers to lose sight of the "big picture." Others note business plans often wind up in a drawer, unused. Some perhaps are afraid to plan, preferring to keep the "Inystery" of their businesses to themselves. Still others view a business plan as limiting a small furm's flexibility, locking the business into a series of actions inconsistent with the needs of a changing environment. While these concerns could have validity in some cases, the many advantages of a business plan - especially a long-term plan - clearly seem to outbalance any potential disadvantages.

\section{Summary and Conclusions}

Simply stated, the business plan is essential to the successful start-up (and continuance) of most small businesses. In addition to providing the necessary decisionmaking data for the venture capitalist, other investors, or lenders that will typically be involved in a firm's funding, the business plan provides the operational directions a firm's management needs to achieve its early goals. Additionally, since the planning process is viewed as continual, it assists in identifying and evaluating the existing firm's attainment of its ongoing goals.

The importance of the business plan is further emphasized by the attention given to it in today's college--level Small Business Management courses. A survey conducted among Small Business Management faculty has revealed that the business plan is considered the most important topic for course coverage. Respondents most definitely recognize that "it all starts with the business planning process" and give it their highest priority. This should be a signal for those considering starting a small business and for those who are already underway. Committing time and resources to planning now enhances the likelihood of achieving success later.

\section{References}

1. Ackelsberg, Robert and Peter Arlow. "Small Businesses Do Plan and It Pays Off." Long Range Planning, October 1985, pp. 61-67.

2. Bryan, E. Lewis and Ralph E. Welton. "Let Your Business Plan Be a Road Map to Credit." Business, April/May/June 1986, pp. 44-47.

3. Hankin, Rock N. and Wilfred J. Bagg. "A Growing Plan: A Written Outline for Success." Management World, 1985, pp. 42-43. 
4. King, Ruth A. "Developing a Business Plan." Business \& Economic Review, July 1985 , pp. 6-9.

5. Larson, Erik. "The Best--Laid Plans," Inc., February 1987, pp. 60-64.

6. Madlin, Nancy. "The Venture Survey: Sticking to Business Plans." Venture, April 1985, p. 25.

7. Ormerod, John and Ira Burns. "The Business Plan: You'll Be Lost Without It." Accountancy, January 1986, pp. 112-113.

8. Rich, Stanley R. and David E. Gumpert. "How to Write a Winning Business Plan." Harvard Business Review, May/June 1985, pp. 156-163.

9. The Small Business Answer Desk Directory. Washington, DC: U. S. Small Business Administration, 1985.

10. The State of Small Business: A Report of the President. Washington, DC: U. S. Government Printing Office, 1987.

11. Welsh, John A. and Jerry F. White. The Entrepreneur's Master Planning Guide. Englewood Cliffs, NJ: Prentice-Hall, Inc, 1983.

\section{Appendix \\ Sample Business Plan Outline}

1. Summary

A. Business description

1. Name

2. Location and plant description

3. Product

4. Market and competition

5. Management expertise

B. Business goals

C. Summary of financial needs and application of funds

D. Earnings projections and potential return to investors

II. Market Analysis
A. Description of total market
B. Industry trends
C. Target market
D. Competition 
III. Products or Services
A. Description of product line
B. Proprietary position: patents, copyrights, and legal/ technical considerations
C. Comparison to competitors' products

IV. Manufacturing Process (if applicable)
A. Materials
B. Source of supply
C. Production methods

V. Marketing Strategy
A. Overall strategy
B. Pricing strategy
C. Method of selling, distributing, and servicing products

VI. Management Plan
A. Form of business organization
B. Board of directors composition
C. Officers: organization chart and responsibilities
D. Resumes of key personnel
E. Staffing plan/number of employees
F. Facilities plan/planned capital improvements
G. Operating plan/schedule of upcoming work for next one to two years

VII. Financial Data
A. Financial statements (five years to present)
B. Five-year financial projections (first year by quarters; remaining years annually)
1. Profit and loss statements
2. Balance sheets
3. Cash flow charts
4. Capital expenditure estimates
C. Explanation of projections
D. Key business ratios

Source: "Financing Small Business." Bank of America Small Business Reporter, Vol. 14, No. 10,1980 , p. 19. 